\title{
OBITUARY: John Nigel Dore, FSA
}

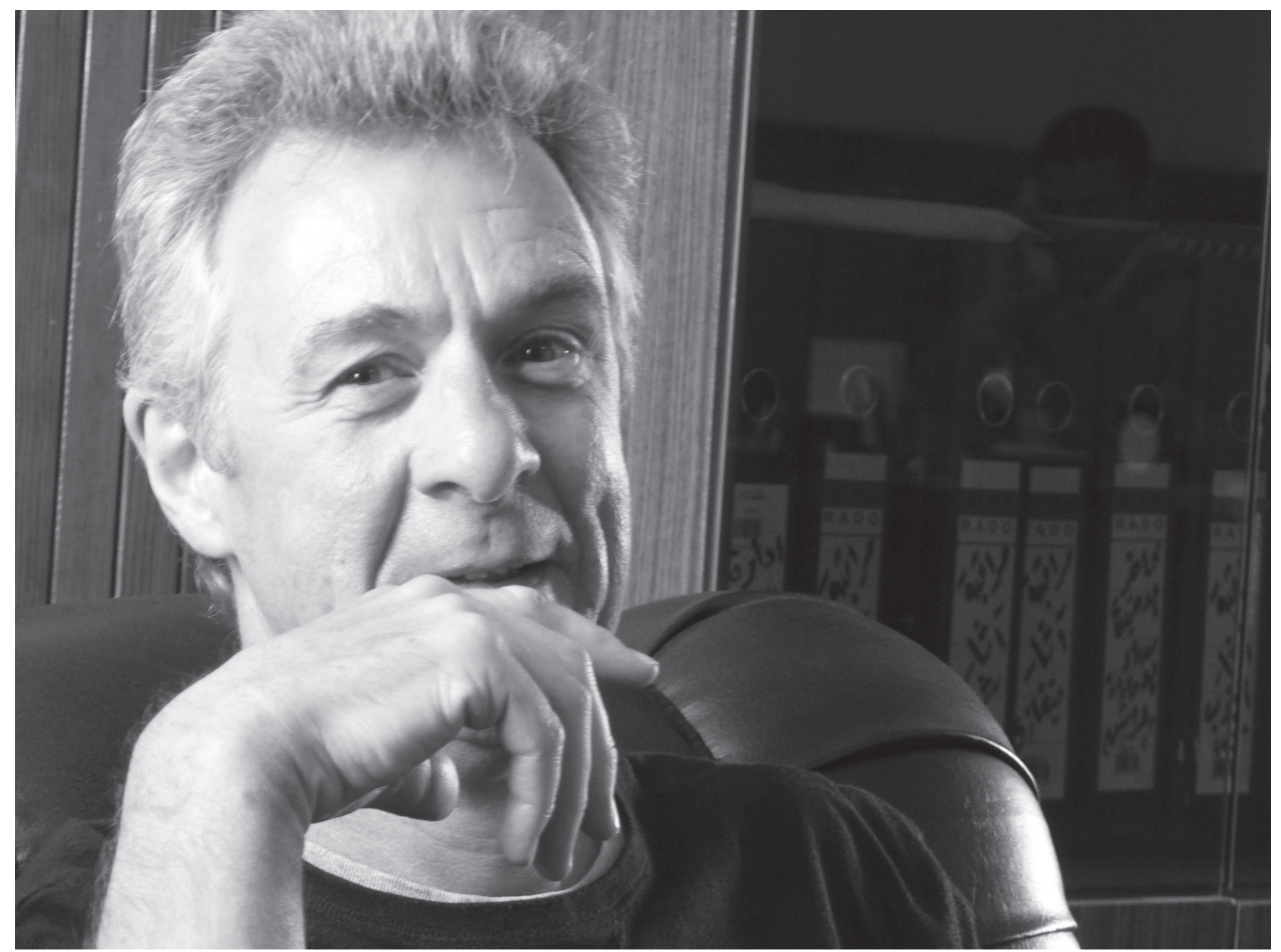

John Dore during his last visit to the Department of Antiquities, Tripoli, in January 2008 (photo: Marta Lahr).

The death of John Dore on 9 June 2008 was both tragic and unexpected. The blood cancer (multiple myeloma) that ended his life so prematurely at the age of only 57 had initially masqueraded as common or garden lower back pain. This was something that had periodically affected him in his adult life, so did not cause immediate concern. Consequently, the disease was already well advanced when the correct diagnosis was reached and intensive chemotherapy failed to halt its aggressive spread. Our thoughts are with his family, who meant so much to him. His passing also represents a huge loss to his many friends, to the archaeological community, to Libya and to the Society for Libyan Studies.

Born in Altringham on 25 March 1951, John inherited some of his interest in the past from his father, the well-known historian of Cheshire, Robert N. Dore. He took a Combined Studies degree in Latin and Archaeology at the University of Birmingham (1969-72) and, scratching around for what to do next, had a fateful meeting with Barri Jones at Manchester University (see Libyan Studies 30 (1999) for Barri's own obituary). Barri promptly dispatched him to join the Society's Sidi Khrebish excavations in Benghazi, initiating John's 36-year love affair with 
Libya and determining that John would indeed pursue an archaeological career (a debt to Barri that he gratefully acknowledged to the end). A second key development was his appointment as John Gillam's research assistant at Newcastle University in 1974, which influenced his chosen specialism in Roman ceramics. John Gillam contributed not only to John's developing expertise in Roman pottery, but required his assistant to deploy considerable people skills too. Gillam was a brilliant but highly idiosyncratic individual, who periodically required bailing out of some unusual difficulty (one source remembers John having to drive to Corbridge late one night to rescue his boss near-naked from a public telephone box!).

In the course of his career, John was involved in a wide range of projects from the northeast of England, to Italy, Portugal and Tunisia. But Libya was a consistent focus throughout his working life, both in terms of field projects and his prominent roles in the Society for Libyan Studies. He was co-author or co-editor of seven monographs and over 50 published articles and pottery reports - a substantial legacy and achievement, despite not having the continuity and security of a permanent academic post and mostly earning his living through short-term contracts and somewhat insecure consultancy work in professional archaeology. John was always much in demand as a ceramicist, a sign of the huge respect he commanded nationally and internationally. He was elected a Fellow of the Society of Antiquaries, London, in 1990.

The work for which John will be best remembered concerns his pioneering classifications and dating of Classical pottery from North Africa - especially Tunisia (Leptiminus), and Libya (Sabratha, the Libyan Valleys Survey and the Saharan region of Fazzan - on all of which, see below). He covered Punic to Islamic sequences in northern Libya and the Neolithic (Pastoral phases) to the recent past in the central Sahara - an incredible geographical and temporal range brought to order in elegantly constructed typologies that have set new benchmarks in the field. Mike Fulford described him to me as 'among the great Mediterranean ceramicists' - a view that I am sure is widely shared by all those who worked closely with him or have engaged with the fine detail of his published outputs. The series of major reports he authored will be the starting point of all future research in this area and in aggregate allow us to start to approach issues relating to regional chronologies and inter-regional trade and exchange at a hitherto unprecedented level of detail. John himself was immensely excited by the potential of carrying this work further himself. Although he has been denied that opportunity, it is to be hoped that one of the several young ceramicists he encouraged (and so generously shared his knowledge and expertise with) will rise to the challenge.

His career can be briefly sketched. As a Research Associate in the Department of Archaeology, University of Newcastle upon Tyne (1974-83; 1986-87) he was particularly involved in bringing to press important work on the Roman frontier (J. Dore and J. Gillam, 1977, The Roman Fort at South Shields: excavations 1875-1975; M.C. Bishop and J. Dore, 1989, Corbridge: excavations of the Roman fort and town, 1947-1980) and quite early on developed expertise in Roman ceramics. He retained his interests in the Roman frontier region all his life and had a particular affection for the site of Corbridge (serving until his death as Treasurer of the Corbridge Excavation Fund). His pottery reports embellish (and enliven) many a northern excavation report published in the last 30 years. Key contributions to highlight include his work for Bill Hanson on the Flavian fort at Elginhaugh and with John Wilkes on the Severan fortress at Carpow. Several other major 
reports are still in press (Halton Chesters, Newstead). Among other notable contributions to Roman pottery research in general, we may note his co-edited set of papers (J. Dore and K. Greene (eds), 1977, Roman Pottery Studies in Britain and Beyond: papers presented to John Gillam) and his co-authored standard work on Romano-British pottery fabrics (J. Dore and R. Tomber, 1998, The National Roman Fabric Reference Collection: a handbook).

Periodically during his long association with the Newcastle Department he was also involved as a Guest Lecturer in teaching students, whether in Roman pottery studies or courses on Roman Britain or Roman Africa. By all reports he excelled at this too, engaging students with his passionate enthusiasm and humour. A more conventional academic career was denied him by the almost complete absence of permanent lectureships advertised in the 1980s. Fortunately, he never allowed himself to become distracted by such disappointments and, despite his considerable skills and abilities, he was never one to denigrate or take a superior tone. John's abilities as a communicator will also be well known to the hundreds of people who visited Tunisia and Libya on the tours that he led over many years. He loved sharing his passionate knowledge of these countries and the quality of his tour leadership drew many plaudits.

He played a leading role as ceramicist on the UNESCO Libyan Valleys Survey (1980-89) - where my own close friendship with him was forged. His detailed pottery report (in D. Mattingly (ed.), 1996, Farming the Desert. The UNESCO Libyan Valleys Survey, Volume 2, Gazetteer and Pottery, 317-89) was complemented by significant contributions to the discussion of settlement types and date ranges (G. Barker (ed.), 1996, Farming the Desert. The UNESCO Libyan Valleys Survey, Volume 1 Synthesis, 111-58).

From 1983 until 1985 he served as curator of the English Heritage Hadrian's Wall Museums, seeing through the opening of a new museum at Corbridge. The museum development was exciting but eventually he became frustrated by the narrowness and administrative focus of the museum role. He jumped at the opportunity of a two-year research fellowship funded by the Society for Libyan Studies (1986-88), leading to the publication of the internationally significant pottery assemblage from Sabratha (J. Dore and N. Keay, 1989, Excavations at Sabratha 1948-1951, Volume 2, part 1, The Finds. The Amphorae, Coarseware and Building Materials).

From 1988 until 1995 he chose to become a self-employed consultant, partly so as to continue to mix contract work in the northeast of England with his Libyan and Arab-world interests, including joining me in 1990 in a new venture, excavating at the Tunisian port city of Leptiminus. The Leptiminus work has so far generated two major monographs, wherein John's pottery reports are recognised as having particular significance (N. Ben Lazreg and D.J. Mattingly, 1992, Leptiminus (Lamta): a Roman Port City in Tunisia Report No. 1, 115-156; L.M. Stirling, D.J. Mattingly and N. Ben Lazreg, 2001, Leptiminus (Lamta) Report No. 2, The East Baths, Cemeteries, Kilns, Venus Mosaic, Site Museum and other studies, 75-98, 205-209).

It was also in this phase that he directed a major field project based on al-Marj (ancient Barca) in Cyrenaica (1989-92). A series of interim reports have appeared on these important Islamic excavations in Libyan Studies 21-25 (1990-1994), but John was still working on the final report for this project at the time of his death. Although al-Marj had been expected to produce significant remains of the Classical city, what John's textbook excavations demonstrated 
was a deep stratified sequence of medieval and early modern Islamic buildings, overlying the possible remains of the Classical and early Islamic town - though his excavations had not been able to establish much detail of the deeply buried initial phases. The project intensified John's interest in Libya's Islamic heritage and the depth of his knowledge and understanding of both archaeological and written sources is well illustrated in his 1994 Libyan Studies paper.

From 1995 until 2002 he returned to the Newcastle Archaeology Department as Director of The Archaeological Practice, its professional archaeological unit. This involved managing all aspects of a commercial archaeological service, operating in a challenging competitive tendering environment. Some of his dealings with large developers he found disturbing and stressful, alien to his character, but key projects that John oversaw in these years include work for the Ministry of Defence in relation to the multi-period landscapes of the Otterburn firing range, the Harehaugh Iron Age hillfort, and at Thirlwell Castle with Northumberland National Park. At the same time, he renewed his working partnership with me on the Fazzan Project (1997-2002), and with Leverhulme Trust support, on bringing to press the unpublished work of Charles Daniels on the Garamantes (1999-2001). To date two monograph reports and numerous interim reports have appeared from this collaboration (see D.J. Mattingly, C.M. Daniels, J.N. Dore, D. Edwards and J. Hawthorne, 2003, The Archaeology of Fazzān, Volume 1, Synthesis; 2007, The Archaeology of Fazzān. Volume 2, Gazetteer, Pottery and Other Finds, especially pp. 305-431 for the pottery type series).

When financial pressures (and short-sightedness) within the University of Newcastle led to the closure of the Practice, he returned to consultancy work again (though often still working with his former colleagues who resurrected The Archaeological Practice as a private venture). Giving up the Directorship allowed him to fulfil a long-term ambition and over two years he completed a Postgraduate Diploma in Advanced Arabic and an MA in Arabic-English Translation from the University of Durham. Although this suggested a possible change of direction in his career, archaeology in fact continued to be his main occupation. Alongside compiling pottery reports for British excavations, he returned periodically to Leptiminus and since 2004 he had become increasingly involved in the Anglo-American project working on Insula VI.1 at Pompeii. When I started to put together a new project in Fazzan, the Desert Migrations Project (DMP), John was the first person I sought to bring on board. He agreed instantly and has been a key player in its initial development, playing a leading role on the core managerial team in our first two seasons (2007-2008; for our second interim report, see this volume). He will be hugely missed by all of us involved with the DMP. He was already experiencing discomforting back pain and a persistent 'virus' when we were in the field in January 2008 - the first symptoms of his illness.

John was a stalwart servant of the Society for Libyan Studies - which he first joined in 1975 (Honorary Secretary 1993-2001; Head of Mission 1998-2008; service on Council in all but three years between 1982-2008; Publications Committee 1993-2002; Fieldwork Committee 1998-2008). He was a great team player and never a primadonna - absolutely dedicated to the cause, but often at his most effective out of sight of the full Council in his facilitating dealings with the Libyan authorities or the external assessors on our Fieldwork Committee and in his 
sage support for a succession of Chairmen and other Officers. Three particular examples typify his contribution. John was largely responsible for negotiating a home for the Society's archive at Newcastle University and for helping to build up this unique resource over the last 20 years. His practical experience of professional archaeology enabled him to give a particularly rigorous lead in developing the Society's detailed Health and Safety policy for its field projects - quickly recognised as a model by the British Academy and commended to other overseas Schools, Institutes and Societies. He also oversaw improvements in the role of external assessors in the Society's allocation of fieldwork grants, making our grants process robust and transparent.

He made huge efforts to become first proficient, then expert, in Arabic, starting with attending intensive courses over several summers in Tunisia in the 1980s, and built on with regular conversation 'classes' with Arabic speakers in Newcastle and through his Durham postgraduate courses. His ability to understand and speak in Arabic was much appreciated in Libya, where he regularly represented the Society's interests to great effect. Nonetheless, his linguistic training in elegant Classical Arabic occasionally led him to express ideas in a language that could disconcert Libyans expecting more colloquial Arabic in conversation - as John himself put it, it could be a bit like "hearing someone speaking perfect Chaucerian English on a Newcastle street today'! His broad interest in and profound knowledge of Islamic architecture and culture were further factors that won him many friends in Libya and Tunisia. The tributes to John that have poured in by email from Libya while I have been writing this piece attest to the unique esteem in which our Libyan colleagues held him.

John was a wonderful colleague in the field - certainly in my own collaborations I found him a perfect (and rightly cautious) foil for my own impetuosity. He made fieldwork fun, though he also always set the highest standards of professionalism. His advice to me was invariably wise, constructive and correct. He was a good manager of people and wore his own expertise lightly, while being extremely generous with his time to those who sought to benefit from his advice and knowledge. His sense of humour was legendary - frequently reducing those he shared workspace with to hysterics by a single word or catch-phrase (often delivered in one of a series of funny voices he cultivated over the years). His facial expressions were equally powerful - the 'cocked head and quizzical raised eyebrow look' will be familiar to many.

New technology and gadgets always delighted John and he could invariably be relied on to amaze me with some new gizmo or software tool whenever we met. He was a notoriously tidy and organised person, seemingly impervious to the mud or dust that sticks to most archaeologists in profusion (again very much my opposite). Even in the desert wastes, far from mod cons, he maintained a well-laundered and freshly ironed look. Many of us will always remember him thus, as a dignified and elegant man. The illness and incapacity in his last weeks must have been hard to bear, though I know he was buoyed by the messages from 'outside'. When we last spoke by phone he confessed to not being immune to 'having a little snivel' now and again over the memories they stirred.

Less well known about John was his engagement with and active support for refugee concerns in Newcastle, giving time, for instance, to North East Refugee Services and offering a warm welcome to numerous incomers (or outsiders) to Newcastle over the years - including Peruvian 
musicians he met through his sons' school, a Turkish TV satellite installer and a Bosnian computer software seller. To quote one Libyan friend who wrote to John in his last days: 'When I visited you, John, in the winter of 1993 the road was never long and this is always the case when friends visit each other'.

John was always happiest when in control of his own timetable and decision-making. He was judicious and something of a perfectionist in his work - hating to hand over a pottery report until he was sure it was completely right. That tendency could from time to time frustrate excavation directors eager to publish their final reports, though in John's case it has led to the creation of a substantial body of work that will prove of enduring value. But that is of scant consolation at this time for his many friends and his family - we must mourn a remarkable and humorous man who did so much to enliven and enrich our lives. Married and divorced at an early age, John was later to have two significant long-term relationships. The first, with Ellen Watts, produced two sons, Tom and Joe, whose company he so treasured - cycling, camping, playing music, hanging out. He is survived by them and by Linda Green, his partner for the past seven years.

ma’as salāma wa shukran jazilan, John

David Mattingly 